\title{
Value Relevance vis-à-vis Disclosure on Business Combinations and Goodwill Recognized by Publicly Traded Brazilian Companies*
}

\author{
Maíra Melo de Souza \\ Universidade Federal de Santa Catarina, Departamento de Ciências Contábeis, Florianópolis, SC, Brazil \\ José Alonso Borba \\ Universidade Federal de Santa Catarina, Departamento de Ciências Contábeis, Florianópolis, SC, Brazil
}

Received on 02.20.2016 - Desk acceptance on 03.12.2016 - $3^{\text {rd }}$ version approved on 09.30.2016

\begin{abstract}
The objective of this study is to examine the value relevance of the level of disclosure on business combinations and goodwill recognized by publicly traded Brazilian companies. The research sample is composed of publicly traded Brazilian companies that carried out any type of business combination, as the acquiring entity, between 2010 and 2013, yielding a total sample of 202 observations. To measure the disclosure level of each, a metric was created based on CPC-15 R1 (2011) to examine certain disclosure items in order to render a greater level of detail. Data collection was carried out using the footnotes to the annual consolidated standardized financial statements (DFPs) available from the São Paulo Stock Exchange (BM\&FBOVESPA) website. The results revealed that disclosure levels for business combinations are positively and significantly associated with the stock price of the companies analyzed. As to the recognition of goodwill during business combinations, despite the fact that it represents a significant share of the value of the transactions, no statistical significance explaining stock price behavior was found. It also bears mentioning that the average level of disclosure identified in the explanatory notes in the sample was very low, indicating that companies need to improve when it comes to transparency of information.
\end{abstract}

Keywords: business combinations, goodwill, disclosure, value relevance. 


\section{INTRODUCTION}

In an economically vulnerable environment, one of the alternatives that companies use in order to become stronger are business combinations (Mortensen, 1994; Chi \& Tang, 2007). Examples of business combinations (corporate reorganizations) include incorporations, mergers, and acquisitions.

The International Accounting Standards Board (IASB) uses the IFRS 3 rule, which addresses business combination transactions and determines how companies should proceed with regards to accounting treatment and disclosure requirements in explanatory notes. Brazil has also adopted this standard via CPC 15 R1 (which correlates with IFRS 3 of the IASB).

However, because it recommends intense use of fair value for accounting and disclosure on business combinations, IFRS 3 is considered to be one of the IASB's most complex standards (Baboukardos \& Rimmel, 2014). Despite the organization's efforts, implementing IFRS 3 is still a big challenge in countries that have adopted its rules (Mario, Baboukardos, Cunningham \& Hassel, 2011).

In Brazil, in light of the challenge presented by the rule addressing business combinations, and in the context of convergence with the IASB standards, studies addressing the mandatory disclosure involved in IFRS 3 thus become relevant. Moreover, Brazil is the perfect environment for comprehensive studies covering the transparency of information contained in published DFPs, considering that it is a developing country which is experiencing various crises involving corruption and lack of transparency.

In this context, disclosure of information on business combinations plays an important role in the sense that it provides users with details regarding the accounting policies adopted and the values related with the transactions carried out (Shalev, 2009).

The importance of mandatory disclosure can also be explained by the agency theory. Laid down by Jensen and Meckling (1976), it shows that earnings management can be used as a result of conflicts of interest in which those who control a company (agent) can manage their decisions with the aim of demonstrating a situation that is compatible with their aims and ambitions, to the detriment of other parties interested in the company's returns. The underlying idea is that those who control company decisions can use this situation to obtain individual benefits to the detriment of other interested parties who do not take part in the decision making process, but who have an interest in the returns that a company can offer.
Thus, regulatory bodies still face difficulties when defining the standards to be followed, as well as researchers, in the sense of providing empirical evidence with regards to mandatory disclosure involved in the accounting rules (Schipper, 2007).

Perhaps because there is no broad theory involving mandatory disclosure, various questions still need to be studied with regards to how to disclose mandatory information and how users view the disclosure carried out (Schipper, 2007).

Moreover, most papers on disclosure originate from countries with the Anglo-Saxon accounting model and address voluntary disclosure; there are still few studies addressing mandatory disclosure in less developed markets (Schipper, 2007; Hassan, Romilly, Giorgioni \& Power, 2009; Baboukardos \& Rimmel, 2014).

Accounting disclosure plays a crucial role in reducing information asymmetry in the context of agency theory (Klann, Beuren \& Hein, 2015). In this sense, companies that carry out better levels of disclosure in their financial statements and explanatory notes are contributing to transparency before the market.

Moreover, another point highlighted by Schipper (2007) is the way users of financial statements view the disclosure carried out by companies. This line of studies includes papers on value relevance.

Studies on value relevance aim to evaluate the relevance of accounting information via how it is reflected in stock prices (Barth, Beaver \& Landsman, 2001; Beaver, 2002; Baboukardos \& Rimmel, 2014; Tsalavoutas \& Dionysiou, 2014).

In Brazil, the expression value relevance is understood as the extent of the impact that particular accounting information causes on company share prices (Ramos \& Lustosa, 2013). Thus, the primary question in studies on value relevance is to know whether the content of accounting statements is relevant for investors (Barth et al., 2001; Beaver, 2002; Lopes, 2002a; Baboukardos \& Rimmel, 2014; Tsalavoutas \& Dionysiou, 2014).

As level of disclosure can be transformed into a numerical variable, some studies have evaluated the relationship between value relevance and levels of disclosure on accounting information. Papers addressing voluntary disclosure include those from Alfaraih and Alanezi (2011), Al-akra and Ali (2012), and Uyar and Kilıc (2012). Studies regarding mandatory disclosure include those from Davis-Friday, Folami, Liu, and Mittelstaedt (1999), Hassan and Mohd-Saleh (2010), Bokpin (2013), 
and Tsalavoutas and Dionysiou (2014). The study from Hassan et al. (2009) covers both mandatory and voluntary disclosure. The results from the aforementioned papers differ, depending on the country in which the research was carried out.

Considering the gap that exists with regards to studies involving mandatory disclosure (Schipper, 2007), the complexity related with IFRS 3 , which addresses business combinations (Mario et al., 2011; Baboukardos \& Rimmel, 2014), and the importance of disclosure in reducing information asymmetry (Leuz \& Verrecchia, 2000; Verrecchia, 2001; Patel, Balic \& Bwakndoira, 2002; Klann et al., 2015), this study intends to contribute to the topic by addressing the value relevance of levels of disclosure on business combinations in the Brazilian emerging market.

Moreover, when addressing business combinations, another important topic that arises is the goodwill recognized in these transactions (Nakayama \& Salotti, 2014).

Goodwill is an asset for which the accounting treatment attributed by the IFRS rules is considered to be complex, with it being the subject of various questions concerning the subjectivity involved in recognizing it in business combinations and subsequent impairment tests (Baboukardos \& Rimmel, 2014).

As the IFRS rules determine the use of fair value in the recording and subsequent accounting treatment of goodwill, researchers criticisms focus on the subjectivity that exists, which paves the way for manager accounting choice, and consequently, earnings management (Hayn \& Hughes, 2006; Petersen \& Plenborg, 2010; Detzen \& Zülch, 2012; Baboukardos \& Rimmel, 2014).

In Brazil, Nakayama (2012) verified that, in 2010, the average percentage of goodwill acquired in business combinations represented $53.16 \%$ of transaction values.

In a survey carried out in 2012 by American Appraisal (a company specialized in evaluating assets and businesses) related to 2010 and 2011 and presented in a paper titled "Global M\&A Valuation Outlook", it was disclosed that in some sectors goodwill values can reach more than $40 \%$ of the values paid in business combinations. The results from the survey reveal that the portions attributed to goodwill are significant.

Some studies have explored the relevance of goodwill created in business combinations, such as Jennings, Robinson, Thompson and Duvall (1996), Henning, Lewis, and Shaw (2000), and Baboukardos and Rimmel (2014). Other studies have investigated the value relevance of total goodwill (accumulated over various years) presented in balance sheets, with the authors of these papers addressing the relevance of intangible assets and covering goodwill with the aim of evaluating its relevance. Examples include the articles from Godfrey and Koh (2001), Dahmash, Durand and Watson (2009), and Olivandira, Rodriguands and Craig (2010). The results from these papers revealed a positive relationship between goodwill values and stock prices.

With the aim of analyzing business combinations and recognized goodwill in the Brazilian setting, the intention behind this study is to provide evidence regarding the way that publicly traded companies are disclosing information on their business combinations, as well as revealing whether the level of disclosure carried out and the goodwill recognized are statistically significant for explaining stock prices.

In light of the above, the following research question was formulated: What is the value relevance of levels of disclosure on business combinations and goodwill recognized in publicly traded Brazilian companies? The research question reveals the aim of this study. This is the first paper in Brazil to address the value relevance of levels of disclosure in business combinations. With the aim of answering the research question, the two hypotheses below were formulated:

H1: There is a positive relationship between levels of disclosure on business combinations in Brazilian companies and their share prices.

$\mathrm{H} 2$ : The value of goodwill recognized by Brazilian companies in business combinations is a significant factor in investors' share price evaluations. 


\section{THEORETICAL FRAMEWORK}

\subsection{Disclosure on Business Combinations and Acquired Goodwill}

Healy, Palepu, and Ruback (1992) analyzed the performance of companies resulting from business combinations in 50 major mergers and incorporations carried out in the United States between 1979 and 1984. The authors demonstrated that the companies obtained improvements in performance post business combination and the results revealed better productivity indices and increases in returns on operating cash flow.

Baboukardos and Rimmel (2014) explain that business combinations are transactions in which an acquirer obtains control of one or more businesses, independent of any compensation involved. In cases in which there is some compensation in exchange for control, this can occur via payment or the promise of payment in money or shares. On the other hand, in situations in which there is no compensation agreement to be honored by the acquirer, the transaction is concluded by solely contractual means. Examples of business combinations include mergers, incorporations, and acquisitions carried out between companies.

The reasons for carrying out business combinations vary from company to company, but authors such as Godoy and Santos (2006) emphasize the search for synergies between companies participating in these transactions, also mentioning the alterations that occur in internal and external market environments, as well as the speed with which new markets to be explored arise. These market factors often make company mergers and acquisitions the fastest and most efficient way to reach more developed markets.

In this economic environment in which companies seek to gain strength by carrying out business combinations, Shalev (2009) highlights the importance of adequate disclosure of information on these transactions in the accounting reports released for external users.

Shalev (2009) argues that the size of the repercussions and economic impact that business combinations can cause in a country makes the importance of adequate disclosure evident, considering that, in many cases, these transactions involve significant amounts of money and important social repercussions, affecting collaborators and society.

In Brazil, accounting pronouncement CPC-15 (R1, 2011), agreeing with the international rule IFRS 3 , determines the disclosure requirements for business combinations carried out in the country. However, as Baboukardos and Rimmel (2014) highlight, IFRS 3 is considered to be one of the most complex of the set of international standards.

The complexity of IFRS 3 begins with the method for acquisitions, which requires the use of fair value in measuring an acquired company's assets and liabilities (Dorata \& Zaldivar, 2010; Mario et al., 2011; Baboukardos \& Rimmel, 2014), also determining that identifiable intangibles, acquired liabilities, goodwill or gain from advantageous purchase, should be recognized on the date of acquisition.

Thus, in a business combination the acquirer should carry out a fair value evaluation of the acquired company's net assets (assets and liabilities at fair value, including contingent liabilities) and should also recognize the identifiable intangibles that did not feature before on the acquired company's balance sheet. The difference between the value of compensation transferred for acquiring control, the value of the acquired company's net assets evaluated at fair value, and the value of recognized identifiable intangibles, constitutes the goodwill (Samkin \& Deegan, 2010; Giuliani \& Brännström, 2011; Detzen \& Zülch, 2012; Martins, Gelbcke, Santos \& Iudícibus, 2013).

It is possible to deduce that, in environments in which business combinations are carried out, intangible assets, among which goodwill features, are ever more important acquired economic resources and represent significant portions in many of these transactions (Chen, Kohlbeck \& Warfield, 2008; Detzen \& Zülch, 2012).

Using the IASB rule IFRS 3 , the accounting treatment of goodwill is highly influenced by fair value, both in initial recognition as well as in subsequent impairment tests, and is the subject of many criticisms regarding its complexity, subjectivity (Baboukardos \& Rimmel, 2014), and the possibility of earnings management (Beatty \& Weber, 2006; Hayn \& Hughes, 2006; Carlin \& Finch, 2010; Jahmani, Dowling \& Torres, 2010; Li, Shroff, Venkataraman \& Zhang, 2011; Detzen \& Zülch, 2012; Ramanna \& Watts, 2012).

Baboukardos and Rimmel (2014) address the complexity of the rule concerning business combinations and goodwill that can arise in these transactions, as well as the relevance of disclosure. They found evidence that goodwill is relevant in companies with greater levels of compliance with the disclosure requirements set out in 
IFRS 3. The next topic considers some of the previous studies on value relevance, highlighting that no previous study was found that addressed the relevance of disclosure with regards to the IFRS 3 rule in particular.

\subsection{Some Previous Studies regarding Value Relevance}

Lopes (2002b) investigated the value relevance of accounting variables (net equity per share and earnings per share) in Brazil. The period analyzed was from 1998 to 1999 . The results revealed that the explanatory power of net equity per share was greater than the explanatory power of earnings per share. The author interpreted the low explanatory power of financial period results, arguing that the high ownership concentration in Brazilian companies means that this information is not crucial for reducing information asymmetry, given that the big controlling shareholders already have privileged access to it.

In Brazil, Rezende (2005) verified the value relevance of net income, net equity, and deferred assets in telecommunications sector companies (new economy) and, comparatively, in companies from the steel/metals and banks/insurers sector (representing the old economy), between 1995 and 2003. The author verified that the accounting variables (earnings per share and net equity per share) are relevant for explaining stock prices in the three sectors analyzed; however, the value of deferred assets did not present statistical significance in any of the sectors.

Kang and Pang (2005) investigated whether the differences in disclosure levels between developed and emerging countries reflects greater value relevance in developed countries. The authors found that the value relevance of accounting information in the United States (a developed country) is greater than the value relevance of information in emerging countries, suggesting that the higher disclosure level in developed countries has an influence on the value relevance of the information provided in accounting reports.
Regarding the relevance of mandatory disclosure levels in an emerging country, the study carried out by Hassan and Mohd-Saleh (2010), in companies in Malaysia, investigated the value relevance of disclosure on financial instruments based on rule MASB 24. The authors report a positive connection between the level of disclosure on financial instruments and stock prices, suggesting that a better level of disclosure regarding financial instruments improves the value relevance of these assets before the market.

Alfaraih and Alanezi (2011) analyzed whether mandatory disclosure levels affect the value relevance of accounting information from the view of investors, in companies listed on the Kuwait Stock Exchange in 2007. They verified that earnings per share are strongly significant for investors in Kuwait, at a 1\% level of significance; and yet, the level of mandatory disclosure variable did not present statistical relevance. The researchers interpreted this result as being due to the inability of many investors to price, in their share price evaluations, better levels of voluntary disclosure.

Tsalavoutas and Dionysiou (2014) analyzed the value relevance of levels of compliance with the IFRS rule and whether there was any difference between companies with high and low levels of compliance in relation to the disclosure requirements of the rule. The study was carried out in Greece, and consisted of a sample of 150 companies. The authors found that compliance with the disclosure requirements is positively and significantly related with stock prices, concluding that information of a mandatory nature is relevant for investors in that they tend to value more transparent companies.

It is possible to note in previous studies that research regarding value relevance tends to find the relevance of net income and net equity, both accounting variables which explain only a small part of a stock's price. In addition, by inserting variables regarding disclosure, some studies have concluded that levels of disclosure are relevant in explaining part of a stock's price. These results in relation to disclosure encourage research in this area aiming to provide more evidence with regards to this fact.

\section{METHODOLOGY}

This study is exploratory-descriptive in nature and in terms of its approach to the problem it covers evaluations of a quantitative and qualitative nature, considering that statistical tools were used to answer the research problem, but a qualitative analysis was also carried out of the disclosure in companies' explanatory notes.
With regards to obtaining the data, the study is classified as documentary. To fulfill the research objectives, disclosure levels had to be measured for the publicly traded Brazilian companies that carried out business combination processes between 2010 and 2013. The data to calculate disclosure levels were obtained from the explanatory 
notes published by the companies, in each case related to the year in which each business combinations occurred.

Thus, if the business combination was carried out on October 15, 2010, the disclosure level analysis was verified in the explanatory notes included in the standardized financial statements (DFPs) related to the financial period ending in 2010. All of the data related to this combination also respected this criterion. In all cases the consolidated DFPs were analyzed.

\subsection{Constructing the Metric and Obtaining Level of Disclosure}

With the aim of measuring the level of disclosure for each business combination in the sample, a disclosure index was calculated based on the information published by the companies in their explanatory notes related to the year in which the business combination occurred.

To obtain each disclosure index, first it was necessary to elaborate a metric covering the information that companies need to release concerning any business combinations carried out.

Nakayama (2012) used a metric based on the CPC-15 determinations (2009). The basis for this author's metric was the first version of the accounting pronouncement related to business combinations. His paper aimed to measure the level of disclosure in business combinations in 2010 and identify factors determining the level of disclosure carried out by Brazilian companies.

The metric developed in this study went beyond those used by Nakayama (2012), given that the requirements contained in CPC-15 R1 (2011) were widened, with the aim of obtaining detailed information on the business combinations and involving a total of 80 items.

The intention was to contribute to fulfilling the completeness attribute envisioned by the CPC Conceptual Framework for Elaborating and Releasing Financial Accounting Reports (2011), which adds that "for information to be faithfully represented it needs to be complete, neutral, and free of errors".

To calculate the disclosure index, the methodology used in research on business combinations by Shalev (2009), Nakayama (2012), and Nakayama and Salotti (2014) was adopted, attributing 1 (one) to "Disclosure of the Item", 0 (zero) to "Non-disclosure of the Item", and NA (Not Applicable) to cases in which particular item(s) of the metric did not apply to the respective case(s).

Each disclosure index was obtained by dividing the number disclosed in explanatory notes by the total number of items of the metric that were applicable for disclosure. The formula below presents the procedure used in calculating the index related to each business combination making up the sample analyzed in this study.

$$
\text { Disclosure Index }=\frac{\text { Number of Items Disclosed in the Explanatory Notes }}{(\text { Total Number of items of the Metric }- \text { Items that do Not Apply) }}
$$

It bears mentioning that each business combination forming the sample was analyzed individually, resulting in an index for each one.

As can be observed in the formula, care was taken in identifying situations in which a particular item of the metric did not apply to the respective case, since these items were not considered in the total reference number for calculating the index. For example, in the companies that recognized goodwill, disclosure of items related to "Gain from Advantageous Purchase" does not apply. Another case of "Not Applicable" concerned the items of the metric in which the company itself communicated, in its explanatory notes, that the respective case did not occur, thus allowing "Not Applicable" to be attributed to that item.

As for the cases in which the company mentioned nothing about the occurrence or not of a particular fact corresponding to some item of the metric, leaving it in doubt whether the fact should have been disclosed or not, it was called "Non Disclosure of the Item", given that it cannot be known whether the fact liable to disclosure occurred.

The argument was assumed that, if the fact did not apply to the company, it could be communicated in its explanatory notes, which would leave no doubt with regards to the occurrence or not of the item.

The decision was taken to analyze the explanatory notes included in the annual accounting statements, called the Standardized Financial Statements (DFPs), given the importance that the information in them represents to the market, since they consider the net income or loss from a financial period.

Similar studies regarding the value relevance of goodwill and/or identifiable intangibles and value relevance of disclosure, conducted by various authors, such as Jandnnings et al. (1996), Handnning et al. (2000), Dahmash et al. (2009), Hassan et al. (2009), Hassan and Mohd-Salandh (2010), Olivandira et al. (2010), 
and Baboukardos and Rimmandl (2014), also used the information from annual accounting statements as the basis for their papers.

\subsection{Presentation of the Variables Used}

In this topic, information is presented on the variables used in the statistical analysis. The dependent variable is represented by stock price (Price). The set of explanatory variables is composed of the level of disclosure on business combinations, goodwill per share, identifiable intangibles per share, relative goodwill, earnings per share (EPS), and book value of net equity per share (BVPS).

\subsubsection{Share price $(P)$ - Dependent Variable.}

In relation to the dependent variable "share price", some studies on value relevance used the share price three months after the closing date of the financial period. Examples include the papers from Vafaei, Taylor, and Ahmed (2011), Jennings et al. (1996), Hassan and MohdSaleh (2010), and Oliveira et al. (2010).

The authors who opted for the methodology involving share price three months after the closing date of the financial period explain that their intention was to test share prices that reflected the information contained in already published annual financial statements. In light of this, in this study the decision was made to use the share price three months after the close of the financial period as a proxy for the dependent variable "share price".

The closing prices of ordinary shares were collected, and when this was not available, the preference share value was used. The data related to share prices were obtained from the ECONOMATICA ${ }^{\circledR}$ database.

\subsubsection{Level of disclosure for business combinations.}

Business combinations are transactions in which an acquirer obtains control of another (acquired) company, thus becoming predominant in the main activities that can affect the acquired company's earnings $(C P C-15 R 1,2011)$.

Considering the size of the impact that business combinations can have on a country's economic environment, adequate disclosure of information regarding these transactions becomes important (Shalev, 2009).

Among the benefits that result from increased corporate disclosure, Healy, Hutton, and Palepu (1999) highlight better company share performance on the market. Along this same line of research, Bushee and Noe (1999) concluded that investors tend to be attracted to companies with greater levels of disclosure.

Some research indicates that a greater level of disclosure results in a reduction in information asymmetry, leading to a reduction in risk, and consequently, reflections of this can be seen in improved share performance in the market (Healy et al., 1999; Malacrida \& Yamamoto, 2006).

In Greece, Baboukardos and Rimmel (2014) found that goodwill has a strong effect on the share price of companies with high levels of goodwill disclosure based on IFRS 3, but no effect on the price of companies with low levels of goodwill disclosure. This is a possible indication that the reduction in risk resulting from greater levels of disclosure is relevant for explaining share prices.

Companies that present a better level of disclosure provide a higher degree of reliability to Brazilian investors (Malacrida \& Yamamoto, 2006). From this perspective, investors are expected to value Brazilian companies with greater levels of disclosure on their business combinations. Hypothesis $\mathrm{H} 1$ of this study states that:

$\mathrm{H} 1$ : There is a positive relationship between levels of disclosure on business combinations in Brazilian companies and their share prices.

The operationalization of the "Disc" variable was via a disclosure index calculated according to the explanation in item 3.1.

\subsubsection{Goodwill per share.}

The test involving the explanatory variable "goodwill per share" intends to provide evidence for accepting or rejecting the second hypothesis formulated in this study. Previous studies have provided statistical evidence that the market attaches relevance to the goodwill recognized by companies, such as those from Jennings et al. (1996), Henning et al. (2000), Godfrey and Koh (2001), Dahmash et al. (2009), Oliveira et al. (2010), and Cazavan-Jeny (2004).

It is worth noting that the papers mentioned studied the value relevance of goodwill in developed countries, and this study provides evidence regarding a developing (emerging) market.

Baboukardos and Rimmel (2014) argued that, in business combinations, the acquirer should evaluate the fair values of assets and liabilities, and verify the existence of identifiable intangibles liable to individual recognition. Only after verifying these values is it possible to evaluate the value of goodwill.

Besides the subjectivity involved in initial recognition, the subsequent accounting treatment of goodwill is also subject to criticism in the literature. On this aspect, Jahmani et al. (2010) observe that the approach of evaluating the recoverable value of goodwill annually, instead of systematic amortization, allows for volatility with regards to financial period results, since losses are 
susceptible to being recognized in varied amounts. For the authors, managers can choose the best moment to recognize losses via impairment, with the aim of carrying out income smoothing.

In this context, the possibility for earnings management is one of the topics under focus when addressing goodwill. Ball, Kothari, and Robin (2000) report that managers can vary the applicability of accounting rules, and in this context, the openness in the rules related to the accounting treatment of goodwill allows for this flexibility.

The value relevance of goodwill was shown by Jennings et al. (1996), in a pioneering paper in which it was revealed that investors use the information available on goodwill acquired in business combinations and that this is reflected in share price. The assumption that the value of goodwill recognized in a business combination is significant at the time investors determine the share price leads to the second hypothesis of the study:

$\mathrm{H} 2$ : The value of goodwill recognized by companies in business combinations is a significant factor in investors' share price evaluations.

Information related to the value of recognized goodwill was obtained from the explanatory notes referring to the years in which the business combinations took place. To operationalize this variable, the value of goodwill recognized in a business combination was divided by the total quantity of company shares, which was obtained from the São Paulo Stock, Commodities, and Futures Exchange (BM\&FBOVESPA) website.

\subsubsection{Identifiable intangible per share.}

For some authors, goodwill is considered as a residual, given that in order to obtain its value the following must be deducted from the transaction value: a) the value of the company's net assets acquired at fair value; and b) the value of the identifiable intangible assets. The remainder thus constitutes the goodwill (Samkin \& Deegan, 2010; Giuliani \& Brännström, 2011; Detzen \& Zülch, 2012; Martins et al., 2013).

In a business combination, only assets that have not fulfilled the recognition criteria for individual (identifiable) intangibles, established by CPC-04 R1 (2010), will be included in goodwill on the date of acquisition.

Thus, in a business combination, acquiring companies should measure the values of the identifiable intangible assets acquired and the portion of intangible assets that were not liable to identification will be included in the value of goodwill acquired in the respective transaction.

It is perceived that the criticisms of the theory related to the subjectivity in recognizing goodwill in business combinations also have an impact on the recognition of identifiable intangibles, since depending on the value that is recognized as identifiable intangible, there will be an impact on the value of goodwill. As a result of this, in this paper, including the variable identifiable intangible per share was considered important.

The "identifiable intangible per share" variable was included with the aim of verifying whether it is statistically significant in relation to share price. The studies from Dahmash et al. (2009) and Oliveira et al. (2010) verified that identifiable intangibles are relevant in Australian and Portuguese investors' evaluations, respectively.

The information regarding the value of recognized identifiable intangibles was obtained from the explanatory notes related to the year in which the business combinations occurred. To operationalize the variable "identifiable intangible per share", the total value of identifiable intangibles, recognized in the respective business combinations, was divided by the total quantity of company shares, which was obtained from the BM\&FBOVESPA website.

\subsubsection{Relative goodwill.}

In various business combinations, it is perceived that the value of goodwill represented a significant portion of the compensation incurred (payment in money, shares, or via assuming obligations to be subsequently honored) by the acquirer in order to acquire control of the acquired company. These cases can be verified in the papers from Shalev (2009) and Nakayama and Salotti (2014).

The "relative goodwill" variable was obtained by dividing the value of goodwill recognized in a business combination by the value of compensation agreed upon in the business combination, and serves to test whether this proportion is relevant for investors with regards to including it in share prices.

Information regarding the value of goodwill acquired in a business combination and the value of compensation agreed upon in the respective transaction were obtained from the explanatory notes related to the year in which the transactions occurred.

\subsubsection{Earnings per share.}

The accounting variable "net income" has been shown to be relevant in various studies on value relevance, which derived from the Olhson (1995) model. Examples include the papers from Rezende (2005), LapointeAntunes, Cormier and Magnan (2009), Oliveira et al. (2010), Alfaraih and Alanezi (2011), Dalmácio, Rezende, Lima, and Martins (2011), Yamaji and Miki (2011), AbuGhazaleh, Al-Hares, and Haddad (2012), and Silva, Macedo, and Marques (2012). 
With regards to emerging markets, as is the case for Brazil, the study from Alfaraih and Alanezi (2011) in Kuwait revealed that earnings per share are strongly significant for investors when evaluating share prices, at a $1 \%$ level of significance. In Brazil, the studies from Rezende (2005) and Silva et al. (2012) also showed that earnings per share are relevant in explaining share prices.

In this study, the relative value of earnings per share was obtained by dividing the value of income from the financial period (collected from ECONOMATICA ${ }^{\oplus}$ ) by the total number of company shares, obtained from the BM\&FBOVESPA website. This approach was chosen for obtaining the data in order to maintain harmony with the way in which goodwill per share and identifiable intangible per share were calculated.

\subsubsection{Net equity per share.}

Some studies on value relevance, based on the Ohlson (195) model, have demonstrated that the variable net equity (NE) is significant for explaining share prices. Examples include the papers from Lopes (2002b), Rezende (2005), Lapointe-Antunes et al. (2009), Oliveira et al. (2010), Dalmácio et al. (2011), Xu, Anandarajan, and Curatola (2011), Yamaji and Miki (2011), and AbuGhazaleh et al. (2012).

Along these same lines and based on the Ohlson (1995) model, the variable referring to net equity per share was used in this study. The value of this variable was obtained by dividing the value of net equity (collected from ECONOMATICA ${ }^{\circ}$ ) by the total number of company shares, obtained from the BM\&FBOVESPA site.

\subsection{Study Sample}

The study sample is composed of all of the publicly traded Brazilian companies which together met the following three conditions: (i) they carried out business combinations in one of the years between 2010 and 2013; (ii) there was a transfer of control in the transaction involved; and (iii) they played the role of acquirer in the transaction carried out.

The information related to the companies that carried out business combinations in the period between 2010 and 2013 was obtained based on the relevant facts published on the Brazilian Securities and Exchange Commission (CVM) website. Thus, all of the relevant facts announcing mergers, incorporations, acquisitions, and spin-offs were analyzed and only the cases in which the business combinations resulted in the transfer of control were selected.

It should be noted that only companies which played the role of acquirer in the business combinations composed the sample; that is, the companies that acquired control after the combinations were carried out.

The transactions that did not result in the transfer of control were not used in the sample, given that in these cases CPC-15 R1 (2011) does not determine the use of the method for acquisition.

Moreover, only cases of business combinations which were effectively concluded were considered when composing the study sample; thus, cases in which combinations were still being negotiated were not considered.

Table 1 shows the composition of the sample with regards to the number of business combinations that were the subject of this study.

Table 1 Composition of the study sample used

\begin{tabular}{ccc}
\hline Year & Number of companies & Number of combinations disclosed \\
\hline 2010 & 29 & 54 \\
\hline 2011 & 28 & 66 \\
\hline 2012 & 29 & 55 \\
\hline 2013 & 16 & 27 \\
\hline Total & 102 & 202 \\
\hline
\end{tabular}

Source: Data from the study. 
As can be observed in Table 1, the number of companies differs from the number of business combinations identified, given that there are companies that carried out various business combinations in the same year. In this study, the sample was composed of business combinations carried out; thus, each business combination is an observation in the sample.

The decision was made to compose the study sample by business combination, and not by company, since level of disclosure and goodwill value recognized per business combination would be analyzed. A sample by company would make this analysis impossible, considering that the average disclosure level and average goodwill value recognized would need to be used in the companies that carried out more than one business combination within the same year, which could distort the results from the study.

Based on this methodology, 202 business combinations were obtained, disclosed in the explanatory notes for the publicly traded Brazilian companies that were the subject of study in this research.

In relation to the types of business combinations analyzed, in accordance with the parameters established for collecting the sample, 192 acquisitions and 10 incorporations were identified.

However, of the 202 business combinations identified, in six cases it was not possible to obtain the share prices, due to this data not being available for consultation in the ECONOMATICA ${ }^{\oplus}$ database. This meant that these six observations could not be used in the multiple linear regression analysis, which uses share price as the dependent variable.

Thus, six business combinations were removed from the sample, these being: Évora, Multiner, Universo Online, Invepar, Berna Participações, and Unidas S.A.. The final sample considered 196 observations for the statistical analyses.

\section{RESULTS FROM THE RESEARCH}

Table 2 presents the results from the descriptive statistic related to the variables used in this study, in which 196 cases of business combinations occurring between 2002 and 2013 were analyzed.

Table 2 Descriptive statistics of the variables used in the study

\begin{tabular}{lcccc}
\hline Variables & Average & Standard Deviation & Minimum & Maximum \\
\hline Share Price & 15.99 & 11.03 & 0.009 & 0.07 \\
\hline Level of Disclosure & 0.29 & 0.10 & 0 & 0.66 \\
\hline Goodwill per Share & 0.17 & 0.59 & 0 & 6.09 \\
\hline Identifiable Intangibles per Share & 0.06 & 0.23 & 0 & 2.15 \\
\hline Relative Goodwill & 0.69 & 1.29 & -0.36 & 16.63 \\
\hline Earnings per Share & 0.58 & 1.07 & -0.001 & 6.49 \\
\hline Net Equity per Share & 4.29 & 7.01 & 32.89 \\
\hline
\end{tabular}

Note. Share Price = share price three months after the close of financial period $n$; Level of Disclosure = disclosure index for the business combinations included in the study sample; Goodwill per Share = goodwill value recognized in a business combination, divided by the total number of company shares; Identifiable Intangibles per Share = total value of identifiable intangibles recognized in a business combination, divided by the total number of company shares; Relative Goodwill= goodwill value divided by the value of compensation related to a business combination; Earnings per Share $=$ net value of earnings (profit or loss) from financial period $n$ (in which the business combination occurred), divided by the total number of company shares; Net Equity per Share = value of Net Equity in period $n$, divided by the total number of company shares.

Source: Data from the study.

It can be perceived in Table 2 that the average level of disclosure carried out by the sample in this study is low (an average of 0.29 ), with the maximum level reaching 0.66 and the minimum level only 0.07 . The analyzed companies need to improve their disclosure on business combinations carried out.

Table 2 also shows that goodwill has a significant value in some business combinations carried out by publicly traded Brazilian companies, considering that the average relative goodwill obtained a value of 0.69 , which indicates that, on average, $69 \%$ of the compensation value paid by the acquirer in the business combinations corresponds to acquired goodwill.

Comparing the maximum goodwill value per share 
with the identifiable intangibles per share, it is found that the value of goodwill recognized in the business combinations analyzed tends to be greater than the value of identifiable intangibles. This result suggests that the companies pay for a set of intangibles that were not individually identified at the time of the transaction, based on the expectation of profitability, which they record in their assets as goodwill.

Complementarily, Correspondence Analysis (ANACOR) was carried out to verify the connection that exists between levels of disclosure and the sectors in which the companies analyzed in this study operate. Figure 1 shows the results verified.

\section{Row and Column Points \\ Symmetrical Normalization}

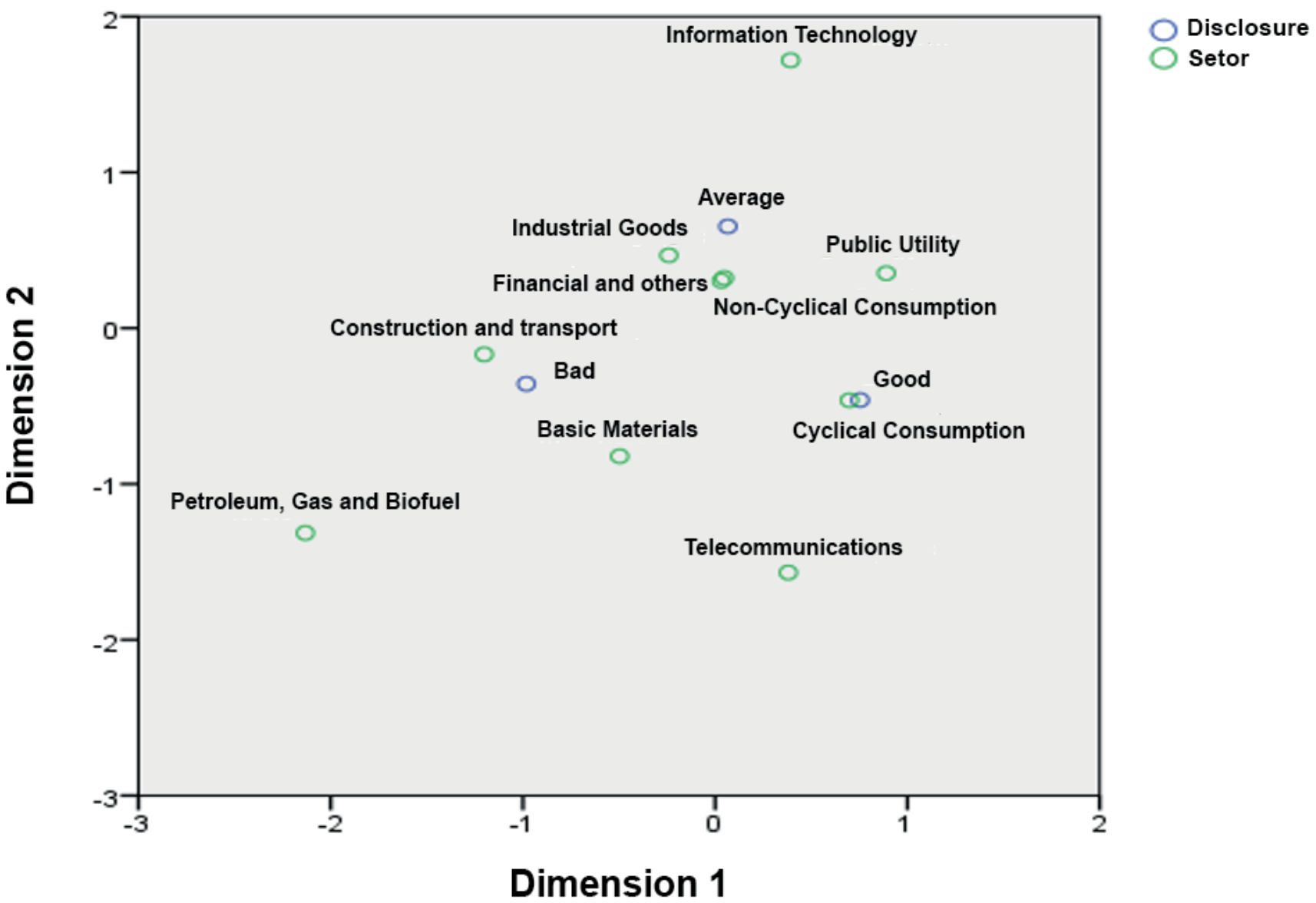

Figure 1. Perceptual map level of disclosure by sector.

Source: Data from the study.

Based on Figure 1, it can be claimed that a connection exists between: (i) good disclosure levels and the cyclical consumption sector; (ii) average disclosure levels and the industrial goods, non-cyclical consumption, financial and others sectors; (iii) bad disclosure levels and the construction and transport and basic materials sectors. These connections are possible due to the closeness in which the related categories are positioned.
Moreover, the public utility sector was between the good and average disclosure levels, given that it is positioned close to the two categories mentioned.

With the aim of finding out whether the level of disclosure on business combinations and goodwill are relevant for explaining share prices, a multiple linear regression model was tested, containing share price as the dependent variable and level of disclosure on business 
combinations, goodwill per share, identifiable intangibles per share, relative goodwill, earnings per share, and net equity per share, as independent variables. Table 3 presents the results found.

Table 3 Results from the multiple regression model

\begin{tabular}{|c|c|c|c|c|}
\hline \multicolumn{5}{|l|}{ Dependent variable: share price } \\
\hline \multicolumn{5}{|l|}{ Observations: 196} \\
\hline \multicolumn{5}{|l|}{ Period: 2010-2013 } \\
\hline Variable & Coefficient & Standard Error & $\mathrm{T}$ & $\mathrm{p}$ Value \\
\hline Constant & 6.804 & 2.701 & 2.519 & 0.013 \\
\hline Level of disclosure & 23.613 & 7.727 & 3.056 & 0.003 \\
\hline Goodwill per share & 0.111 & 1.505 & -0.076 & 0.939 \\
\hline Identifiable intangible per share & -5.632 & 3.519 & -1.601 & 0.111 \\
\hline Relative goodwill & -0.25 & 0.596 & -0.42 & 0.675 \\
\hline Earnings per share & 1.84 & 1.137 & 1.618 & 0.107 \\
\hline Net equity per share & 0.365 & 0.184 & 1.985 & 0.049 \\
\hline \multicolumn{5}{|l|}{ F: 5.098} \\
\hline \multicolumn{5}{|l|}{$p$ value: 0.000} \\
\hline$R^{2}: 14.10 \%$ & & Adjusted: 11.30 & & \\
\hline
\end{tabular}

Source: Data from the study.

The "p value" from the model was 0.000 , revealing that it is significant to $1 \%$; that is, the explanatory variables that compose the model are together significant for explaining the dependent variable "share price".

The value of $\mathrm{R}^{2}$ indicates that $14.10 \%$ of the variations in the share prices of publicly traded Brazilian companies that carried out business combinations between 2010 and 2013 can be explained by a model involving the following variables: level of disclosure on business combinations carried out in the year, goodwill per share, identifiable intangible per share, relative goodwill, earnings per share, and net equity per share.

However, by carrying out an individual analysis regarding the explanatory power of each variable composing the model, only the "level of disclosure on business combinations carried out in the year" and "net equity per share" are significant to $5 \%$, for explaining the dependent variable "share price". Both are positively associated with share price, which suggests that the greater the level of disclosure and net equity per share, the higher the price attached to the share.

It should be noted that the variable "level of disclosure on business combinations carried out in the year" presented $1 \%$ significance, agreeing with hypothesis 1 in this study. On the other hand, hypothesis 2 was rejected, given that the variable "goodwill per share" was not significant in the regression model.

The result from the regression model also allows it to be observed that the variable "earnings per share" was significant to $10 \%$, with a positive coefficient, which suggests that the higher the earnings per share, the higher the share price.

The greater explanatory power of net equity per share in relation to earnings per share is consistent with the results already revealed in the study from Lopes (2002b), in which the author explains that this result may be related with the fact that most companies in Brazil have a concentrated ownership structure and that this may affect the relevance of net income.

The variables "identifiable intangible per share" and "relative goodwill" presented a negative coefficient, which could suggest that the higher the value of these variables, the lower the share price would be; yet, neither demonstrated statistical significance in the model, and thus, the results from this study do not support such inferences regarding these two variables.

With regards to the validity assumptions in the regression model, for collinearity analysis the VIF and Tolerance tests were carried out. Table 4 presents the results found. 
Table 4 VIF and Tolerance Tests

\begin{tabular}{llc}
\hline Variables & VIF & Tolerance \\
\hline Level of Disclosure & 1.124 & 0.889 \\
\hline Goodwill per Share & 1.415 & 0.707 \\
\hline Identifiable Intangible per Share & 1.197 & 0.835 \\
\hline Relative Goodwill & 1.054 & 0.949 \\
\hline Earnings per Share & 2.659 & 0.376 \\
\hline Net Equity per Share & 2.958 & 0.338 \\
\hline Average VIF & $\mathbf{1 . 7 3}$ & \\
\hline
\end{tabular}

Source: Data from the study.

The results from the two tests reveal that the model does not present problematic collinearity, given that the VIF values were not higher than 3 and the Tolerance test values were not lower than 0.10 .

With regards to residual homoskedasticity, the Pesarán-Pesarán test was carried out, which according to Cunha and Coelho (2009) was developed to examine the existence of homoskedasticity; that is, whether the variance in residuals remains constant over the whole range of independent variables. When this assumption is not met, a heteroskedasticity problem exists, and measures need to be taken to correct this problem. The hypotheses tested are: $\mathrm{H} 0$, indicating that the residuals are homoskedastic, and $\mathrm{H} 1$, representing that the residuals are heteroskedastic.

The Pesarán-Pesarán test resulted in a Sig. value of 0.960 , accepting the null hypothesis that states that the residuals are homoskedastic. Therefore, there is no problem of heteroskedasticity in the model.

Residual normality was analyzed using the Kolmogorov-Smirnov (K-S) test. The Sig. value from the K-S test resulted in 0.121 . This result indicates that the test for the model accepted hypothesis $\mathrm{H} 0$, which attests that the distribution is normal. Thus, the assumption of normality was fulfilled.

\section{CONCLUSIONS}

This study aimed to verify the value relevance of levels of disclosure on business combinations and of the goodwill recognized in publicly traded Brazilian companies. The results from the study showed that:

i. The variable "level of disclosure" on business combinations was positively significant to $1 \%$ for explaining share prices in the sample analyzed;

ii. The variable "net equity per share" was positively significant to $5 \%$ for explaining share prices in the sample analyzed;

iii. The variable "earnings per share" was positively significant to $10 \%$ for explaining share prices in the sample analyzed; and

iv. The variables "goodwill per share", "identifiable intangible per share", and "relative goodwill" recognized in the business combinations were not significant for explaining share prices in the sample analyzed.

In relation to the value relevance of disclosure on business combination carried out by Brazilian companies, the results revealed that investors tend to value companies that provide more information regarding transactions carried out, thus confirming hypothesis $\mathrm{H} 1$ in this study.

The results suggest that shares in companies that present a greater level of disclosure, on average, tend to be more highly valued by investors. These results are consistent with the findings of Hassan and Mohd-Saleh (2010).

In relation to the value relevance of goodwill recognized in business combinations, hypothesis $\mathrm{H} 2$ was rejected and the results suggest that the value of goodwill recognized in business combinations is not relevant for explaining share prices in Brazil. This result may be related with the low level of goodwill disclosure in Brazil.

Despite the results related to the value relevance of goodwill not presenting significance, it is important to highlight that, by comparing maximum value of goodwill per share with identifiable intangibles per share, it is found that the goodwill value recognized in the business combinations analyzed tends to be higher than the value of identifiable intangibles. This result allows for it to be suggested that, in a lot of the business combinations 
occurring in Brazil between 2010 and 2013, the companies were not able to recognize intangibles that qualified for individual recording, thus allocating the largest portion to goodwill.

Additionally, the average level of disclosure on business combinations in Brazil is low, and it is not sufficient for providing an adequate overview of the methods used and of the corresponding assets acquired in business combinations; thus, investors appear to value companies with greater transparency.

However, it is important to stress that the results from this study are limited to the sample and period analyzed; that is, they cannot be generalized for other companies or different periods.

Also worth highlighting as a limitation in this study is the fact that the metric used to measure levels of disclosure was elaborated based solely on CPC 15 (R1) and did not cover other normative bases. Moreover, the data was collected using the qualitative method, and in this case, the role of the researcher was crucial in analyzing the disclosure carried out by the companies.

Another limitation in this study relates to the fact that the companies did not carry out business combinations in all of the years, making a time series analysis of the level of disclosure in the sample impossible.

It is suggested, for subsequent research, that a comparative study be carried out involving the value relevance of levels of mandatory disclosure in Brazilian (emerging market) companies and companies located in a developed market.

\section{REFERENCES}

AbuGhazaleh, N. M., Al-Hares, O. M., \& Haddad, A. E. (2012). The Value Relevance of goodwill impairments: UK Evidence. International Journal of Economics and Finance, 4(4), 206-216.

Al-Akra, M., \& Ali, M. (2012). The value relevance of corporate voluntary disclosure in the Middle-East: The case of Jordan. Journal of Accounting and Public Policy, 31(5), 533-549.

Alfaraih, M. M., \& Alanezi, F. S. (2011). Does voluntary disclosure level affect the value relevance of accounting information? Accounting \& Taxation, 3(2), 65-84.

American Appraisal (2012). Global M\&A Valuation Outlook. Retrieved from http://www.american-appraisal.com.br/AAFiles/Library/PDF/GlobalMAValuationOutlook.pdf.

Baboukardos, D., \& Rimmel, G. (2014). Goodwill under IFRS: Relevance and disclosures in an unfavorable environment. Accounting Forum, 38(1), 1-17.

Ball, R., Kothari, S. P., \& Robin, A. (2000). The effect of international institutional factors on properties of accounting earnings. Journal of Accounting and Economics, 29(1), p. 1-51.

Barth, M. E., Beaver, W. H., \& Landsman, W. R. (2001). The relevance of the value relevance literature for financial accounting standard setting: another view. Journal of Accounting and Economics, 31(1), 77-104.

Beatty, A., \& Weber, J. (2006). Accounting discretion in fair value estimates: an examination of SFAS 142 goodwill impairments. Journal of Accounting Research, 44(2), 257-288.

Beaver, W. H. (2002). Perspectives on recent capital market research. The Accounting Review, 77(2), 453-474.

Bokpin, G. A. (2013). Determinants and value relevance of corporate disclosure. Journal of Applied Accounting Research, 14(2), 127-146.

Bushee, B. J., \& Noe, C. F. (1999). Disclosure quality, institutional investors, and stock return volatility. Retrieved from https://www.researchgate.net/profile/Christopher Noe/publication/228171436_Disclosure_Quality_ Institutional_Investors_and_Stock_Return_Volatility/ links/0deec52a05b6a45390000000.pdf.
Carlin, T. M., \& Finch, N. (2010). Evidence on IFRS goodwill impairment testing by Australian and New Zealand firms. Managerial Finance, 36(9), 785-798.

Cazavan-Jeny, A. (2004). Le ratio market-to-book et la reconnaissance des immatériels - une étude du marché français. Comptabilité-Contrôle-Audit, 10(2), 99-124.

Chen, C., Kohlbeck, M., \& Warfield, T. (2008). Timeliness of impairment recognition: Evidence from the initial adoption of SFAS 142. Advances in Accounting, 24(1), 72-81.

Chi, L-C., \& Tang, T-C. (2007). Impact of reorganization announcements on distressed-stock returns. Economic Modelling, 24(5), 749-767.

Comitê de Pronunciamentos Contábeis (2011). Pronunciamento Técnico CPC 15 R1, de 03 de junho de 2011. Combinação de negócios. Retrieved from http://www.cpc.org.br/CPC.

Comitê de Pronunciamentos Contábeis (2010). Pronunciamento Técnico CPC 04 R1, de 05 de novembro de 2010. Ativo intangível. Retrieved from http://www.cpc.org.br/CPC.

Dahmash, F. N., Durand, R. B., \& Watson, J. (2009). The value relevance and reliability of reported goodwill and identifiable intangible assets. The British Accounting Review, 41(2), 120137.

Dalmácio, F. Z., Rezende, A. J., Lima, E. M., \& Martins, E. (2011). A relevância do goodwill no processo de avaliação das empresas brasileiras. BASE - Revista de Administração e Contabilidade da Unisinos, 8(4), 359-372.

Davis-Friday, P. Y, Folami, L. B., Liu, C.-S., \& Mittelstaedt, H. F. (1999). The value relevance of financial statement recognition vs. disclosure: evidence from SFAS no. 106: The Accounting Review, 74(4), 403-423.

Detzen, D., \& Zülch, H. (2012). Executive compensation and goodwill recognition under IFRS: Evidence from European mergers. Journal of International Accounting, Auditing and Taxation, 21(2), 106-126.

Dorata; N. T., \& Zaldivar, I. P. (2010). Fair value and business combinations. Review of Business, 30(2), 31-39. 
Giuliani, M., \& Brännström, D. (2011). Defining goodwill: a practice perspective. Journal of Financial Reporting and Accounting, 9(2), 161-175.

Godoy, C. R., \& Santos, A. (2006). Contabilidade para fusões e aquisições de empresas: soluções históricas para problemas contemporâneos. Revista de Administração, 41(1), 29-42.

Godfrey, J. M., \& Koh, P-S. (2001). The relevance to firm valuation of capitalizing intangible assets in total and by category. Australian Accounting Review, 11(24), 39-48.

Hassan, M. S., \& Mohd-Saleh, N. (2010). The value relevance of financial instruments disclosure in Malaysian firms listed in the main board of Bursa Malaysia. Int. Journal of Economics and Management, 4(2), 243-270.

Hassan, O. A. G., Romilly, P., Giorgioni, G., \& Power, D. (2009). The value relevance of disclosure: Evidence from the emerging capital market of Egypt. The International Journal of Accounting, 44(1), 79-102.

Hayn, C., \& Hugues, P. J. (2006). Leading indicators of goodwill impairment. Journal of Accounting, Auditing \& Finance, 21(3), 223-265.

Healy, P. M.; Palepu, K. G., \& Ruback, R. S. (1992). Does corporate performance improve after mergers? Journal of Financial Economics, 31(2), 135-175.

Healy, P. M., Hutton, A. P., \& Palepu, K. G. (1999). Stock performance and intermediation changes surrounding sustained increases in disclosure. Contemporary Accounting Research, 16(3), 485-520.

Henning, S. L, Lewis, B. L., \& Shaw, W. H. (2000). Valuation of the components of purchased goodwill. Journal of Accounting Research, 38(2), 375-386.

Jahmani, Y., Dowling, W. A., \& Torres, P. D. (2010). Goodwill impairment: a new window for earnings management. Journal of Business \& Economics Research, 8(2), 19-23.

Jennings, R., Robinson, J., Thompson, R. B., \& Duvall, L. (1996). The relation between accounting goodwill numbers and equity values. Journal of Business Finance \& Accounting, 23(4), 513533.

Jensen, M. C., \& Meckling, W. H. (1976). Theory of the firm: managerial behavior, agency costs and ownership structure. Journal of Financial Economics, 3(4), 305-360.

Kang, T., \& Pang, Y. H. (2005). Economic development and the value-relevance of accounting information - a disclosure transparency perspective. Review of Accounting and Finance, 4(1), 5-31.

Klann, R. C., Beuren, I. M., \& Hein, N. (2015). Canonical relationship between performance indicators based on Brazil, US and IFRS accounting standards of Brazilian and United Kingdom companies. Journal of Accounting and Taxation, 7(1) $1-12$.

Lapointe-Antunes, P., Cormier, D., \& Magnan, M. (2009). Value relevance and timeliness of transitional goodwill-impairment losses: Evidence from Canada. The International Journal of Accounting, 44(1), 56-78.

Leuz, C., \& Verrecchia, R. E. (2000). The economic consequences of increased disclosure. Journal of Accounting Research, 38 (supplement: Studies on Accounting Information and the Economics of the Firm), 91-124.
Li, Z., Shroff, P. K, Venkataraman, R., \& Zhang, I. X. (2011). Causes and consequences of goodwill impairment losses. Rev Account Stud, 16(4), 745-778.

Lopes, A. B. (2002a). A informação contábil e o mercado de capitais. São Paulo: Pioneira Thomson Learning.

Lopes, A. B. (2002b). The Value Relevance of Earnings and Book Values in Brazil: Old versus New Economy. In Anais do $26^{\circ}$ Encontro Nacional da Associação Nacional de Pós-Graduação e Pesquisa em Administração, Salvador, BA, Brasil.

Malacrida, M. J. C., \& Yamamoto, M. M. (2006). Governança corporativa: nível de evidenciação das informações e sua relação com a volatilidade das ações do Ibovespa 2006. Revista de Contabilidade \& Finanças, 17 (edição especial), 65-79.

Mario, C., Baboukardos, D., Cunningham, G. M., \& Hassel, L. G. (2011). The impact of IFRS on reporting for business combinations: an in-depth analysis using the telecommunications industry. In Annals of the Faculty of Economics, University of Oradea, 1(1), 557-593. Retrieved from http://steconomiceuoradea.ro/anale/volume/2011/n1/054.pdf.

Martins, E., Gelbcke, E. R., Santos, A., \& Iudícibus, S. (2013). Manual de Contabilidade Societária: aplicável a todas as sociedades de acordo com as normas internacionais e do CPC. São Paulo: Atlas.

Mortensen, R: (1994). Accounting for business combinations in the global economy: purcharge, pooling, or? Journal of Accounting Education, 12(1), 81-87.

Nakayama, W. K. (2012). Divulgação de informações sobre operações de combinação de negócios na vigência do pronunciamento técnico CPC 15 (Master's Degree). Faculdade de Economia, Administração e Contabilidade, Universidade de São Paulo, São Paulo, SP, Brasil.

Nakayama, W. K., \& Salotti, B. M. (2014). Fatores determinantes do nível de divulgação de informações sobre combinações de negócios com a entrada em vigor do pronunciamento técnico CPC 15. Revista de Contabilidade \& Finanças, 25(66), 267-280.

Ohlson, J. A. (1995). Earnings, book values, and dividends in equity valuation. Contemporary Accounting Research, 11(2), 661-687.

Oliveira, L., Rodrigues, L. L., \& Craig, R. (2010). Intangible assets and value relevance: evidence from the Portuguese stock exchange. The British Accounting Review, 42(4), 241-252.

Patel, S. A., Balic, A., \& Bwakira, L. (2002). Measuring transparency and disclosure at firm level in emerging markets. Emerging Markets Review, 3(4), 325-337.

Petersen, C., \& Plenborg, T. (2010). How do firms implement impairment tests of goodwill? ABACUS - A Journal of Accounting, Finance and Business Studies, 46(4), 419-446.

Ramanna, K., \& Watts, R. L. (2012). Evidence on the use of unverifiable estimates in required goodwill impairment. Rev Account Stud, 17(4), 749-780.

Ramos, D. A., \& Lustosa, P. R. B. (2013). Verificação empírica da value relevance na adoção das normas internacionais de contabilidade para o mercado de capitais brasileiro. Contexto, 13(25), 70-83.

Rezende, A. J. (2005). The relevance of accounting information in the process of valuation of companies in the new and old economy - an analysis of asset investments and their effects 
on the value relevance of earnings and book value. $B B R$ Brazilian Business Review, 2(1), 33-52.

Samkin, G., \& Deegan, C. (2010). Calculating non-controlling interest in the presence of goodwill impairment. Accounting Research Journal, 23(2), 213-233.

Schipper, K. (2007). Required disclosures in financial reports. The Accounting Review, 82(2), 301-326.

Shalev, R. (2009). The information content of business combination disclosure level. The Accounting Review, 84(1); 239-270.

Silva, A. F., Macedo, M. A. S., \& Marques, J. A. V. C. (2012). Análise da relevância da informação contábil no setor brasileiro de energia elétrica no período de 2005 A 2007: uma discussão com foco nas variáveis LL, FCO E EBITDA. Revista Universo Contábil, 8(2), 6-24.

Tsalavoutas, I., \& Dionysiou, D. (2014). Value relevance of IFRS mandatory disclosure requirements. Journal of Applied Accounting Research, 15(1), 22-42.

Uyar, A., \& Kilıc,.M. (2012). Value relevance of voluntary disclosure: evidence from Turkish firms. Journal of.Intellectual Capital, 13(3), 363-376.

Vafaei, A., Taylor, D., \& Ahmed, K. (2011). The value relevance of intellectual capital disclosures. Journal of Intellectual Capital, 12(3), 407-429.

Verrecchia, R. E. (2001). Essays on disclosure. Journal of Accounting and Economics, 32(1), 97-180.

Xu, W., Anandarajan, A., \& Curatola, A. (2011). The value relevance of goodwill impairment. Research in Accounting Regulation, 23(2), 145-148.

Yamaji, N. \& Miki, J. (2011). The value relevance of goodwill and goodwill amortization: evidence from listed Japanese companies. BA Business \& Accounting Review, 7, 19-30.

\section{Address for correspondence:}

Maíra Melo de Souza

Universidade Federal de Santa Catarina, Departamento de Ciências Contábeis

Campus Reitor João David Ferreira Lima, s/n - CEP: 88040-900

Trindade - Florianópolis - SC - Brazil

Email: maira.souza@ufsc.br 